\title{
MINIMISING LOSS OF CRAYFISH AND HABITAT DURING WORKS ON WATERCOURSES
}

\author{
S. PEAY
}

\begin{abstract}
Scott Wilson, The Design Innovation Centre, 46 The Calls, Leeds, LS2 7EY, UK. E-Mail: crayfish@brydens.org.uk
\end{abstract}

Reçu le 8 septembre 2003

Accepté le 21 novembre 2003

Received September 8, 2003

Accepted November 21, 2003

\begin{abstract}
Works in watercourses with white-clawed crayfish Austropotamobius pallipes cause temporary or permanent loss of habitat and crayfish. Past modifications can also leave waterbodies unfavourable for crayfish, but sometimes there is scope to improve them. Mitigation measures can reduce the impact and reinstate or even improve habitat. Various case studies show measures used during engineering works and some of the problems. Good planning and supervision are vital. The big issues at river and catchment scales (non-indigenous crayfish, disease, water quality and landuse) may be higher priorities than provision of habitat at site or reach level; e.g. fencing in pastures improves riparian areas for crayfish and other species. If necessary, there are various options for natural and artificial refuges, but their success depends on flow characteristics, substrate and accessibility. Microhabitat can make the difference between success and failure.
\end{abstract}

Key-words: white-clawed crayfish, habitat, restoration, mitigation.

\section{GESTION DES POPULATIONS : MINIMISER LES PERTES D'ÉCREVISSES ET D'HABITAT LORS DE TRAVAUX D'AMÉNAGEMENT DES COURS D'EAU}

\section{RÉSUMÉ}

Les travaux d'aménagement réalisés dans les cours d'eau possédant une population d'Austropotamobius pallipes sont la cause d'une perte, temporaire ou permanente, d'écrevisses ou de leur habitat. De plus, les modifications des rivières réalisées par le passé ont parfois laissé un habitat peu favorable aux écrevisses. Certaines mesures peuvent être prises pour réduire l'impact de ces travaux et même améliorer l'habitat. Plusieurs cas démontrent l'utilisation de ces méthodes par des ingénieurs. Une planification et une supervision adéquates sont vitales à la réussite de ces projets. Les problèmes rencontrés au niveau de la rivière ou du bassin (écrevisses non-indigènes, maladies, qualité de l'eau, gestion des sols) peuvent avoir priorité sur l'amélioration de la qualité de l'habitat au niveau du site (par exemple mettre une clôture aux pâturages). Des refuges naturels ou artificiels peuvent être installés, mais leur succès dépend du débit, du substrat et de leur accessibilité. Le micro-habitat peut faire la différence entre un succès ou un échec.

Mots-clés : écrevisses à pattes blanches, habitat, amélioration, restauration. 


\section{INTRODUCTION}

In the UK there is a widespread but declining population of white-clawed crayfish Austropotamobius pallipes (SIBLEY et al., 2002; SIBLEY, 2003). This is due to crayfish plague Aphanomyces astaci, competition from non-indigenous crayfish, and loss of habitat or reduction of quality. The species is listed in the EU Habitats and Species Directive (1992) in Annex II, which requires member states to designate Special Areas for Conservation for the named species, and in Annex V, which requires states to maintain the species in favourable conservation status. In the UK there is also the Wildlife and Countryside Act 1981 (as amended). From 1988 the white-clawed crayfish was added to the list of species protected from "taking or sale" under Schedule 5 of the Act.

Ideally, all existing populations of white-clawed crayfish should be left undisturbed where they occur. Sometimes, however, works have to be carried out in waterbodies and these may cause temporary or permanent loss of habitat and loss of crayfish. Both stillwaters and running water may be affected, but most of the case studies given here are from rivers and canals.

In the UK, there is a strict requirement for anyone planning works in sites with a statutory designation for nature conservation to assess the potential impact of any proposed works; to avoid impacts wherever possible; to provide mitigation measures where impacts cannot be avoided, and where appropriate to provide compensation for loss or damage that cannot be mitigated. Outside designated sites the degree of protection is less clear. White-clawed crayfish do not have the same high level of legal protection as species for which protection is given for both individuals and the habitats in which they occur.

A licence is required for surveys to be undertaken, but there is no statutory protection for white-clawed crayfish or their habitat, if authorised works affects these. Nonetheless, in England and Wales the Environment Agency (EA) has byelaws that require anyone proposing to carry out works within a specified distance from a main river to obtain permission from the statutory agency prior to commencing works. The EA can impose conditions on works to safeguard species and habitats. In addition to its regulatory role, the EA has responsibilities for flood defence and manages some rivers directly. It has internal procedures for environmental assessment for all major projects and for routine operations. Often is it civil engineering contractors, employed by organisations other than the EA, who carry out the works in waterbodies. Environmental mitigation measures of various kinds generally form part of the project design, prepared by clients and their consultants and approved by the statutory agency. On site, the client for the project may commission environmental work directly, i.e. separately from the contract for construction; or it may be the responsibility of the contractor to obtain a specialist where necessary.

This review uses examples of projects carried out in England in waterbodies with white-clawed crayfish. Most of the projects involved construction works in watercourses and in all cases the purpose of the project was not specifically conservation of whiteclawed crayfish. They were all projects that involved mitigation measures for crayfish, or habitat enhancement was primarily for another species. The projects were mainly smallscale. The degree of advance survey and subsequent monitoring varied. Contractors usually undertake any required engineering work in rivers with guidance and technical support from consultants or statutory agencies. Although the projects may be reported to agencies locally, they are rarely presented in published literature. This is especially so if they have not been wholly successful. Nonetheless, it is cases that show both the opportunities and the problems that are most useful in guiding work in future.

All the examples are ones in which the author has had some involvement, or has been provided with information from others directly involved. For clarity, each case study is given as a whole and then particular issues raised by these examples are discussed. 


\section{POTENTIAL IMPACTS OF WORKS}

Works that can have adverse impacts on populations of crayfish include the construction or repair of built structures, reinforcement of banks against erosion, and river maintenance operations. Depending on the nature and detail of the works, these activities may lead to direct loss of refuges used by crayfish in the channel and in the banks, or may cause the death of crayfish. In addition, works may have indirect impacts, for example through the release of silt and other materials into the water that may affect crayfish downstream. Past modifications may also have left waterbodies partly or wholly unsuitable for crayfish, although sometimes there is scope to improve them. Measures described here to mitigate the impact of construction work may also be applicable when considering the improvement of waterbodies that have been modified in the past. Wider issues should be considered; specifically, whether there are any existing threats to whiteclawed crayfish within the catchment, such as non-indigenous crayfish species (NICS), before commencing any habitat improvement work. Table 1 shows a matrix of potential impacts on crayfish that may occur due to works.

Works involving construction, near the top of the table, will usually require planning approval and may be subject to a formal process of environmental impact assessment (EIA), depending on the scale of the project overall. Further down the table, dredging and management of vegetation may not be subject to any control and is often undertaken by local landowners. Both locally and cumulatively, however, small-scale management of rivers can have significant impacts on crayfish and other species.

Construction projects often necessitate de-watering of the channel, or lowering of the water level in still waters. Dry working reduces the risk of siltation and pollution incidents. Draining the bed exposes crayfish to air. White-clawed crayfish are damaged by exposure to air longer than 48 hours (TAYLOR and WHEATLY, 1981). By contrast signal crayfish Pacifastacus leniusculus have been found in dried out riverbeds in England (HOLDICH et al., 1995) and have survived wholly out of water for at least 11 weeks (PEAY, 1997). De-watering leads to damage or death of white-clawed crayfish from exposure and to increased risk of predation from birds and mammals. For example, the author has had reports of flocks of gulls (Larus spp.) and crows (Corvus spp.) feeding on white-clawed crayfish during de-watering to repair a weir on the River Wharfe, Yorkshire.

\section{CASE STUDIES}

\section{Case study 1 - construction work in Meanwood Beck, Leeds}

Meanwood Beck is a small, stony stream, which runs through a wooded valley that drains adjacent suburban areas in Leeds, West Yorkshire. The geology in the catchment is Carboniferous sandstone. The water in the stream is mildly nutrient-enriched by urban drainage, but was known to support a population of white-clawed crayfish (BRICKLAND, 1996; BROWN, 1996). Nonetheless, the intermittent discharges of untreated effluent from combined sewer overflows (CSO) were causing litter in the stream. This was considered to be socially unacceptable in a valley that is an important, council-owned public park. The regional water company proposed a scheme to reduce sewer overflows by installing a large sewer main. The works involved a pipeline crossing the stream in an open-cut trench, plus a new outfall about $100 \mathrm{~m}$ downstream. For both components of the works there was a requirement to de-water part of the stream, using a temporary flume-pipe to bypass the area of works.

No detailed surveys of crayfish were carried out immediately prior to the works. In summary, the mitigation measures carried out prior to any excavation in the channel involved manual clearance of all stone that could potentially provide a refuge for crayfish. 


\section{Table I}

\section{Potential Impact of Works in Rivers.}

Tableau I

Impact potentiel des travaux en rivière.

\begin{tabular}{|c|c|c|c|c|c|}
\hline \multirow[t]{2}{*}{ Operation } & \multicolumn{3}{|c|}{ Potential Impacts } & \multirow[b]{2}{*}{$\begin{array}{l}\text { Indirect } \\
\text { impacts }\end{array}$} & \multirow[t]{2}{*}{ Comments on Impacts } \\
\hline & $\begin{array}{l}\text { Disturb } \\
\text { channel }\end{array}$ & De-water & $\begin{array}{l}\text { Disturb } \\
\text { banks }\end{array}$ & & \\
\hline $\begin{array}{l}\text { Construct/ } \\
\text { repair bridge }\end{array}$ & Yes & Yes & Yes & $\begin{array}{l}\text { Possible } \\
\text { siltation/ } \\
\text { pollution }\end{array}$ & $\begin{array}{l}\text { Damaged masonry may be used by } \\
\text { crayfish. Concrete bridge piles have } \\
\text { no refuges. Scale of impact depends } \\
\text { on design and scale of work. Possible } \\
\text { siltation or pollution during construction. }\end{array}$ \\
\hline $\begin{array}{l}\text { Construct } \\
\text { outfall }\end{array}$ & Possibly & Yes & Yes & $\begin{array}{l}\text { Siltation/ } \\
\text { pollution }\end{array}$ & $\begin{array}{l}\text { Usually localised impact. May require } \\
\text { reinforcement of channel bed at outfall. } \\
\text { Discharge may reduce water quality } \\
\text { locally. }\end{array}$ \\
\hline $\begin{array}{l}\text { Construct } \\
\text { pipeline } \\
\text { crossing }\end{array}$ & Yes & Yes & Yes & $\begin{array}{l}\text { Possible } \\
\text { siltation/ } \\
\text { pollution }\end{array}$ & $\begin{array}{l}\text { Cut and cover in de-watered channel } \\
\text { is usually cheapest for small rivers. De- } \\
\text { watering localised and short duration. } \\
\text { May be permanent loss of habitat. }\end{array}$ \\
\hline $\begin{array}{l}\text { Repair canal } \\
\text { washwall or } \\
\text { dam }\end{array}$ & Yes & Yes & Yes & $\begin{array}{l}\text { Possible } \\
\text { siltation/ } \\
\text { pollution }\end{array}$ & $\begin{array}{l}\text { Loss of refuges. De-watering may be } \\
\text { extensive or prolonged. }\end{array}$ \\
\hline Divert channel & Yes & Yes & Yes & $\begin{array}{l}\text { Possible } \\
\text { siltation }\end{array}$ & $\begin{array}{l}\text { Total loss of channel. New one may not } \\
\text { have habitat for crayfish. Some siltation } \\
\text { when carry out diversion. }\end{array}$ \\
\hline $\begin{array}{l}\text { Drainage from } \\
\text { construction } \\
\text { sites }\end{array}$ & No & No & No & $\begin{array}{l}\text { Siltation/ } \\
\text { possible } \\
\text { pollution }\end{array}$ & $\begin{array}{l}\text { May increase silt downstream and risk } \\
\text { of pollution. }\end{array}$ \\
\hline Reinforce bank & Possibly & Possibly & Yes & $\begin{array}{l}\text { Possible } \\
\text { siltation }\end{array}$ & $\begin{array}{l}\text { Permanent loss of refuges with } \\
\text { sheet-piling, concrete or mortared } \\
\text { brickwork. May create new refuges with } \\
\text { unmortared stone or woody material. }\end{array}$ \\
\hline Regrade bank & Possibly & No & Yes & Siltation & $\begin{array}{l}\text { Loss of bank complexity and associated } \\
\text { refuges. May be extensive if for flood } \\
\text { defence. }\end{array}$ \\
\hline Dredging & Yes & Possibly & Possibly & Siltation & $\begin{array}{l}\text { Loss of crayfish among aquatic plants } \\
\text { and in burrows. Discharge of silt during } \\
\text { works. Often very extensive. }\end{array}$ \\
\hline $\begin{array}{l}\text { Remove trees } \\
\text { on banks }\end{array}$ & No & No & Possibly & & $\begin{array}{l}\text { Temporary loss of shade and leaf litter } \\
\text { if coppice. May be permanent loss } \\
\text { of refuges among roots if trees are } \\
\text { grubbed out. }\end{array}$ \\
\hline $\begin{array}{l}\text { Remove debris } \\
\text { dams }\end{array}$ & No & No & Yes & $\begin{array}{l}\text { Possibly } \\
\text { loss of } \\
\text { food }\end{array}$ & $\begin{array}{l}\text { Routine maintenance for flood defence } \\
\text { - loss of refuges and litter as food } \\
\text { source. }\end{array}$ \\
\hline $\begin{array}{l}\text { Remove stock } \\
\text { fencing, or } \\
\text { increase stock } \\
\text { in unfenced } \\
\text { pasture }\end{array}$ & Possibly & No & Yes & $\begin{array}{l}\text { Siltation/ } \\
\text { pollution }\end{array}$ & $\begin{array}{l}\text { Access of stock tramples banks and } \\
\text { sometime bed. Loss of refuges in } \\
\text { banks, reduction/loss of emergent and } \\
\text { submerged plants. Direct pollution } \\
\text { from livestock. Increased erosion and } \\
\text { siltation. }\end{array}$ \\
\hline
\end{tabular}


The cobbles and boulders were stored for use in re-instatement. The stream was blocked with sandbags either side of the working area and the flow directed down a $600 \mathrm{~mm}$ diameter pipe, de-watering the bed of the channel. All crayfish found were removed and relocated in suitable habitat locally, away from the area affected by the works (SCOTT WILSON, 1998a).

The first phase of work was the new CSO outfall, carried out in dry conditions in late July. The design for the new outfall included hard surfacing of the streambed to reduce scouring on occasions when the CSO discharged during high flows in both sewer and stream. Following discussion with the site agent, cobbles and boulders on the left bank and a mature tree were retained opposite the outfall, rather than having both the channel bed and the opposite bank cleared and surfaced with large, unmortared stones. A few metres of the right bank on either side of the CSO were faced with unmortared stones (stone-revetting).

The works on the CSO outfall went largely to plan. There were, however, the common problems of getting pumps of sufficient capacity on site and enough sandbags for the de-watering exercise, sources of delay. An area of $37 \mathrm{~m}^{2}$ was searched prior to the draw down, as the water was shallow (less than $0.4 \mathrm{~m}$ ) and clear. The channel bed was systematically cleared by hand, and 31 white-clawed crayfish were removed. This is a reasonably high density, considering the area cleared was mainly a riffle. In this stream the most favourable refuges are in the banks and in the slower-flowing glides. All the crayfish found were in the most sheltered sections, with none at all in the fastest-flowing, shallow areas, even though there was a lot of large $(15-25 \mathrm{~cm})$ cobble present there.

Silt-blankets (barriers made of a fleece-like fabric) were used downstream of the working area to reduce siltation during disturbance of the bed. These allowed water to pass through, but trapped a proportion of the displaced sediment. De-watering was carried out the day after clearance of the bed. The gravel and pebble streambed, left after clearance the previous day, was checked for crayfish using rakes and hand-nets. No crayfish were found there. When de-watering commenced, crayfish started emerging from refuges in the banks within 10 minutes of exposure to air. In all, 19 animals emerged from approximately $10 \mathrm{~m}$ of bank; 13 of these within 20 minutes and the rest during a period of 2 hours. Supervised excavation started when no crayfish had emerged for at least 30 minutes.

Taken together, the population density was 1.3 crayfish $\mathrm{m}^{-2}$ for the whole channel in the area affected by works. If the most suitable habitat is considered separately from the faster riffles, however, a zone $0.5 \mathrm{~m}$ by $10 \mathrm{~m}$ along the left bank and a further $2 \mathrm{~m}^{2}$ in a small pool in the margin on the right bank had most of the crayfish, equivalent to a density of 4.8 crayfish $\mathrm{m}^{-2}$; whilst the riffle in the rest of the channel had a density of approximately 0.5 crayfish $\mathrm{m}^{-2}$.

All rescued crayfish were relocated to natural refuges in favourable habitat 50-100 m downstream. Usually, an upstream site would be preferable, but in this case the proposed pipeline crossing was less than $100 \mathrm{~m}$ upstream and immediately downstream of a culvert under a dual carriageway. As the culvert is possibly a partial barrier to the movement of crayfish, it was decided to keep the crayfish downstream of this structure.

At the site for the CSO outfall, the right bank was excavated to create the opening for the outfall structure, set back from the stream. The streambed was paved on the same day as dewatering occurred. Salvaged cobble was then put back on the unpaved areas and along the margins, although sandbags were placed to isolate the excavated area of bank from the stream during the period of construction work.

The construction of the sewer pipeline did not reach Meanwood Beck until November, because a period of wet weather slowed the rate of work on the site. Female 
white-clawed crayfish were berried by this time and so the timing was not ideal. With the sewer main already under construction, the crossing of the stream could not be deferred until the following July, the time when white-clawed crayfish in Yorkshire release their young. This time there was no prior clearance of the channel, as the flow was too fast to make a crayfish rescue feasible prior to the start of de-watering. A section some $5 \mathrm{~m}$ wide and $7 \mathrm{~m}$ long $\left(35 \mathrm{~m}^{2}\right)$ was cleared. The total catch was 91 , an average density of 2.6 crayfish $\mathrm{m}^{-2}$. This may be an underestimate, because the flume pipe was installed and construction staff had started the de-watering before the crayfish team reached the site, contrary to the mitigation plan.

At this site too, the crayfish were localised within the channel. Crayfish were found mainly in an undercut section of wall and under a cracked area of re-inforced concrete, which was prised out with an excavator so it could be searched manually. Juveniles of less than $25 \mathrm{~mm}$ carapace length $(\mathrm{CL})$ represented $19 \%$ of the total catch. This probably means that juveniles were under-recorded, especially the $0+$ and $1+$ animals. Rescued animals were moved to favourable habitat in a $50 \mathrm{~m}$ length of stream upstream of the new CSO outfall.

As with the outfall, stone taken from the bed was stored carefully for use in the reinstatement. The crayfish removal and the cut and cover pipeline were completed within one day. The construction of new stone-revetted banks and reinstatement of the bed were carried out subsequently. The pipeline and its concrete capping were too shallow for the crossing to be reinstated as a glide with cobble and boulder. The contractor simply covered the pipeline with a layer of clay and used the salvaged cobble as part of the general fill material on the construction site.

There was no provision for any monitoring of crayfish after the works. The stream between the CSO and the pipeline has, however, been studied throughout 1999 and in subsequent years by PEAY and HILEY (unpublished work). At the CSO outfall, the new stone-revetted banks are only covered by water during high flows and do not normally offer any refuges for white-clawed crayfish. The interstices between the stone slabs paving the bed were left unmortared, but soon filled by sand and gravel. Nonetheless, following some damage during floods in autumn 2000 , some crevices have been opened up. Night-viewing studies (observations of crayfish at night by torch-light) confirmed that crayfish occasionally use the paved area. The flow is too shallow and fast over most of the stonework for it to be used for refuges. Nonetheless, it does not appear to be a barrier to the movement of crayfish. The rest of the stream between the outfall and the pipeline crossing upstream has maintained a population of crayfish.

By contrast, the pipeline crossing was wholly unsuitable for crayfish for four years. Winter floods eventually scoured off the clay, causing siltation in the study area downstream. By spring 2003, the concrete cap was exposed and a scour hole had developed immediately downstream. Ironically, if this starts to damage the concrete casing of the pipeline, suitable, relatively stable refuges may become available again.

\section{Case study 2 - pipeline crossing, Eller Beck, Skipton}

In North Yorkshire, the installation of a $55 \mathrm{~km}$ major water pipeline from Skipton to the villages of Settle and Ingleton necessitated numerous crossings of limestone streams. Most of these watercourses were unsuitable for crayfish, being either seasonally dry, culverted, polluted, or lacking in potential habitat. Others were in river catchments with no recent records of white-clawed crayfish, although all of these watercourses were manually surveyed around the proposed crossing sites. One of the streams that did have crayfish was subject to similar mitigation measures to those carried out in Meanwood Beck. This was Eller Beck, near Skipton (SCOTT WILSON, 1998b). No crayfish were found during the localised clearance of the bed. The stream was a moderately steep riffle at this point, relatively unsuitable for white-clawed crayfish. 
The pipeline crossing was not carried out immediately after the clearance of the bed. There was a delay of several days while the construction progressed to Eller Beck, because work was delayed in various parts of the pipeline route by heavy rain and high flows. Furthermore, when the cut-and-cover crossing was carried out, a section of bank downstream of the area of the pipeline crossing was excavated to install large boulders to reinforce the bank. This area was within in the de-watered zone, but because it was relatively stable prior to works, it was not included in the work to remove crayfish before the start of excavation. A few crayfish were found on the streambed after the clearance but before the excavation started, following a flood event in which they may have been washed downstream or sought refuge in the disturbed bed.

A total of 16 crayfish was recorded during the de-watering of a $15 \mathrm{~m}$ section of the stream and the excavation of an area of the bank to allow large stones to be bedded. The actual excavation and installation of the pipeline was completed well within a day. The contractor carried out the reinstatement of the streambed later. It involved scattering salvaged stone over the set concrete of the pipeline casing. The route of the temporary flume pipe was left as an open channel, leaving a small island in the channel. There was no provision for monitoring, but an inspection for white-clawed crayfish in 2003 confirmed that whilst other aquatic invertebrates had colonised the stones in the crossing area, white-clawed crayfish had not. The cobbles were relatively sparse on the bed and many were sitting loosely on the concrete, with few or no interstices available to crayfish.

\section{Case study 3 - de-watering in canals}

The Huddersfield Narrow Canal, a waterway route across the Pennine Hills in West Yorkshire, is undergoing restoration work to reopen it to canal traffic after a period of disuse. The canal dates from the $18^{\text {th }}$ century and along many sections, in the urban areas especially, the banks are lined with un-mortared stone walls. These walls, plus miscellaneous urban debris, provide refuges for localised but abundant populations of white-clawed crayfish. In 2000, work was carried out to repair an aqueduct. This involved creating temporary bunds or dams within the canal and de-watering a $20 \mathrm{~m}$ section of canal during the winter. Three successive drawdowns yielded over 500 crayfish (PEAY, observation; N. BIRKINSHAW, British Waterways, pers. comm.). This was a surprisingly high abundance, considering the silty condition of the bed and only moderate water quality.

The need to install concrete walls in the aqueduct caused permanent loss of the refuges in the washwalls. Artificial refuges were installed to allow crayfish to continue using the washwalls. New concrete walls had several rows of perforated plastic pipes attached horizontally along the walls. These had plastic netting attached to provide a "scramblenet" as access for crayfish. Subsequently, night-viewing confirmed that white-clawed crayfish were using the new structures (E. KEMP, PhD student, University of Staffordshire, pers. comm.).

A de-watering exercise on a much greater scale was carried out in the Leeds Liverpool Canal in Bingley, West Yorkshire, to allow the construction of a new road bridge across the canal, (J. BRICKLAND, British Waterways, Leeds, pers. comm.). The bridge was constructed in two separate sections, each one requiring de-watering of the canal for a period of many weeks. The two phases of work were separated by about a year, but were undertaken during the winter because British Waterways is obliged to maintain the canal as a public navigable waterway from April to October.

For the first de-watering, the whole canal pound was de-watered, over $400 \mathrm{~m}$ in length. Staff of British Waterways carried out a crayfish rescue. The length of canal affected meant that although several hundreds of crayfish were removed, many more were 
probably lost to predation and exposure. Residual areas along the bottom of the canal remained wet, but it is not known how much of this was suitable for crayfish.

The following year, the de-watering exercise was repeated to allow the work on constructing the piers of the other half of the bridge. This time, temporary bunds were installed and the water was pumped around the working area in a series of large pipes, limiting the de-watered area to about $150 \mathrm{~m}$. The critical time to carry out removal of crayfish in a canal is from the point half way down the washwalls to the exposure of the first metre or so of the bed. Further down, there tends to be less refuge material and much more silt. Unfortunately, the contractors could not easily predict the rate of drawdown and the level fell all the way to the bed overnight. This was quite suitable for removal of fish by electro-fishing, but fewer than 10 crayfish were recovered from stones in the channel and the lower wash walls. Additional pumps were used to empty the canal completely so it could be searched thoroughly, but no more crayfish were found.

\section{Case study 4 - reinforcing a stream bank}

One of the small tributary streams of the River Ribble, North Yorkshire, is Long Preston Beck. It is a small, shallow watercourse, about $4 \mathrm{~m}$ wide with a cobble bed and a moderately steep gradient, about $30 \mathrm{~m} / \mathrm{km}^{-1}$. The geology is mainly limestone, with some shale and clay exposed in the stream banks locally. A railway line crosses the stream valley on an embankment and by a bridge. Immediately upstream of the embankment the stream bank was approximately $3 \mathrm{~m}$ high and actively eroding. Reinforcement of about $80 \mathrm{~m}$ of stream bank was necessary to safeguard the railway, with the new work tying-in to existing stone-revetting at the bridge.

Prior to the works a survey was carried out, using selective manual search (PEAY, 2003a) of 10 refuges in each of the 5 most favourable habitat patches in the $100 \mathrm{~m}$ site. It was supplemented with selective search of a further 50 refuges, to provide a total of 50 each in the slow-flowing glide at the upstream end of the site and in the faster-flowing, steeper riffle adjacent to the eroding bank. The standard 50-refuge survey of the whole site averaged 0.8 crayfish/10 refuges, a low abundance. None were recorded in the riffle. In the glide a search of 50 stones averaged 1.2 crayfish/10 refuges, although here too the banks were eroding and some areas had been partly reinforced with gabion baskets (large boxes of steel mesh filled with stones). The flow rate through the riffle was such that even under low flows it was comparatively unfavourable for crayfish. Survey conditions were difficult too in the riffle, as the patches most likely to support crayfish were the few places where the cobble was piled several layers deep on the bed, conditions that reduce search efficiency.

The works involved clearing all the cobble from a zone about $1.5 \mathrm{~m}$ wide along the foot of the eroding bank, about a third of the channel width (PEAY, 2002a). This was done manually to allow any crayfish to be removed and relocated in refuges in the glide upstream. All machine-working was from the top of the bank, except immediately adjacent to the railway bridge. Lack of space and requirements for railway safety necessitated an excavator travelling along an exposed shingle bed down the right side of the channel. The bed was not fully de-watered, but 1 tonne sandbags were lowered into place to reduce the flow overall and direct it away from the working area. This formed a barrier to the movement of crayfish downstream from the unaffected area of the glide. Straw-bales were used as silt-traps immediately downstream of the working area and an absorbent fabric boom was positioned across the channel to mop up any oil or hydraulic fluid that seeped from the excavators. The foot of the eroding bank and the adjacent streambed was excavated to create a flat footing below the level of the streambed. It and the exposed bank were then lined with a strong, synthetic textile, to prevent fine substrate from the bank being washed by natural drainage into the interstices of the coarse fill material behind the new wall of 
stone blocks. The roughly shaped cuboid blocks were approximately $0.6 \mathrm{~m}$ in length. The first row was lowered into place on the textile-covered bed and clean $100 \mathrm{~mm}$ stone fill was placed behind the blocks. Successive rows of blocks were seated on top, each row partially overlapping the one below to create a stepped wall. The stone initially removed from the streambed was piled up against the toe of the wall, leaving water-filled interstices between the first row of blocks and among the cobble and boulders at the foot. Once completed, this provided some $80 \mathrm{~m}$ of bank with potential refuges for crayfish along its length.

The bed clearance yielded 4 crayfish from $9 \mathrm{~m}^{2}$ of glide, the only area of slowflowing channel affected by the works, and 10 crayfish were removed from $60 \mathrm{~m}^{2}$ of the riffle. This is equivalent to population densities of 0.4 and 0.17 crayfish $\mathrm{m}^{-2}$ respectively.

Unlike many projects, this one included a post-project survey in summer 2003. This confirmed that there was a similar abundance of crayfish in the upstream glide (4 crayfish from 50 stone search, 0.8 crayfish/10 refuges). The riffle still had a very low abundance, below the limit of detection using a selective manual survey. The new bank retains interstices that appear to be potentially favourable for crayfish. There are small patches of slow flowing or still water among the large cobbles and stone blocks. The bank and its cobble and boulder footing is now too stable for any manual searching and the depth of water over the cobble is too shallow for trapping. Night-viewing will be carried out in future to try to confirm whether crayfish are using the new bank.

\section{DISCUSSION}

\section{Impacts of construction}

The case studies give a few examples of relatively small-scale construction projects that are often carried out in watercourses in England. None of the examples were on projects of a scale large enough to require a mandatory environmental impact assessment, with the exception of the new road bridge over the canal, which was part of a new $6 \mathrm{~km}$ road scheme. Hence, whether any mitigation is carried out depends on the local regulatory authority for rivers and the degree to which those responsible for implementing the works follow best environmental practice.

As the examples from the pipeline crossings and canals show, construction work has direct impacts on the channel and banks, although the impacts may be localised to a few metres or 10 s metres. The works all cause at least temporary loss of habitat and in some instances the loss is permanent. As case study 2 showed, even when stone from the riverbed is replaced after works, conditions may not be favourable for crayfish. SMITH et al. (1996) showed the association between white-clawed crayfish and slow-flowing glides or pools, with few in riffles or areas with a lot of small cobble. PEAY (2002b, 2003b) found that the areas with the greatest abundance of crayfish had large, flattened cobbles and boulders over fine gravel and sand, into which the crayfish could burrow. Consequently, re-instatement of pipelines as shallow riffles is unfavourable for crayfish.

Even if the pipeline is set low enough in the ground that a pool or glide can be created, cobble and boulder placed on the streambed will not provide any refuges unless it is piled closely and deeply enough to create interstices sufficiently large for crayfish to use as refuges. Putting stone over concrete does not provide any underlying substrate for burrowing. Gravel and sand could be laid over the surface prior to covering the bed with cobble and boulder, but the material will only stay there if the shape of the channel and the characteristics of the flow are such that it is not washed out during the first high flows in the winter. The depth at which the pipeline crosses the stream is important. For example, 
if the bottom of the trench is only $1 \mathrm{~m}$ below bed level, the pipe is $60 \mathrm{~cm}$ diameter and capped with $50 \mathrm{~cm}$ depth of concrete, the surface of the concrete will already be $10 \mathrm{~cm}$ above the old bed level. In a deep, slow-flowing watercourse this might make little difference. However, in a small stream that was originally only $30 \mathrm{~cm}$ deep during normal summer conditions, this could turn an area of highly favourable glide into a fast-flowing run that is wholly unsuitable for crayfish.

In watercourses that are subject to periodic high flows, stable refuges in banks are particularly important to crayfish. In both the pipeline crossing and the CSO outfall in Meanwood Beck (case study 1), unmortared stone-revetting was used to stabilise the banks. This is a traditional method of bank-reinforcement in Yorkshire, used to varying heights up the banks of this watercourse and many others locally, in both urban and rural areas. Where there are gaps between the stones and these are submerged, the crevices can be used as refuges by crayfish. The new stone-revetting in Meanwood Beck was next to flat areas of earth or gravel in the channel and was dry during average to low flows. The stone-revetting could be used only occasionally during very high flows, if at all. Crayfish could not use the interstices in the new revetting on the bed of the channel, except possibly during high winter flows and even then only for short periods. By contrast, the bank reinforcement at Long Preston (case study 4) retains water filled crevices, even during low flows and is potentially much more favourable for crayfish than the actively eroding bank that was there previously.

De-watering may not cause any long-term loss of habitat in itself, but it exposes the bed. This may cause loss of some or all of the white-clawed crayfish population in the area and the more extensive the de-watering, the greater the loss.

Most of the canals in England were constructed in the late $18^{\text {th }}$ to early $19^{\text {th }}$ centuries and white-clawed crayfish are likely to have colonised these from the streams used to feed the canal system. Occasionally, sections of canal $100 \mathrm{~s}$ metres in length or more have been drained to allow the repair of lock gates or other structures. Crayfish must have been able to recolonise from unaffected sections over time, but there is little or no information about how quickly this occurs in canals. Available evidence from rivers is that the rate of colonisation by white-clawed crayfish is rather slow after a population is lost from an area. SPINK and FRAYLING (2002) carried out surveys of populations that were re-introduced to a stream after an outbreak of crayfish plague. They showed that even 4-8 years after the introductions, the population detected in the surveys was mainly within 10 s to a few 100 s metres of the reintroduction sites. This is in accord with radio-tracking studies (ROBINSON et al., 2000; ARMITAGE, 2000); which show that individual crayfish may have a limited range, within a few metres of a refuge, and only occasionally move over greater distances of $10 \mathrm{~s}$ to $100 \mathrm{~s}$ metres if displaced.

If there is a population of crayfish at high abundance upstream or downstream of the works area, it is likely that recolonisation will be faster than if the population is naturally at relatively low density. For example, a population may be reduced at irregular intervals by periodic flood events that are sufficient to scour out refuges and occupying crayfish. PEAY and ROGERS (1999) suggested that an invading population of signal crayfish might have to reach some critical density before it started spreading within a watercourse. They estimated an average rate of downstream colonisation of approximately $1 \mathrm{~km}$ year for signal crayfish, although colonisation by both signal crayfish and white-clawed crayfish can occur in both directions.

The repeated de-watering of the Leeds Liverpool Canal (case study 3) suggests that there was a significant impact on the population of white-clawed crayfish during the first episode of de-watering and that there had been very little recolonisation of the $400 \mathrm{~m}$ section from adjacent areas in the course of a year. Several years are likely to be necessary for full recovery at that site. 


\section{Mitigation measures}

Construction project designers and project managers may need guidance on measures to minimise the impact on white-clawed crayfish. Ideally, this should occur as soon as possible at the planning stage of any construction project (PEAY, 2000).

De-watering may be essential to allow construction work to be carried out. Dry working can also prevent or reduce siltation due to runoff from ground disturbed during the works. It reduces the risks of pollution, especially from fuel, oil or other lubricants from machinery, or from new cement or other chemicals. De-watering should be kept to the minimum extent that is practicable, to reduce impacts on crayfish and other aquatic life. Unless the extent of de-watering is planned in advance in the method of works, it can be difficult to forecast the necessary scale of any removal of crayfish, or fish.

Routing pipelines through riffles rather than glides, may reduce the impact on crayfish, but could increase in the impact on other species, for example spawning areas for brown trout (Salmo trutta) or Atlantic salmon (Salmo salar).

If there is a need to create refuges for crayfish, either as part of the re-instatement of habitat after works, or in compensation for permanent loss of habitat elsewhere, there are several options. The success of these depends on attention to detail. As the pipeline case studies show, micro-habitat matters. The flow, substrate, orientation and accessibility of refuges will affect their usage.

Table 2 lists different types of refuges. These are grouped in three types, the use of stone on the bed or banks, use of trees, wood or other vegetation and artificial refuges. It appears that crayfish will use natural or artificial refuges, provided these satisfy the basic requirements: large enough for the crayfish, resistant to high flows and relatively secure against predators or other crayfish. FOSTER (1993) showed that there is a relationship between refuge size and body size in crayfish. In watercourses subject to highly variable flows crayfish select refuges in banks and under the largest stones that offer void spaces. In stony streams in Yorkshire, they are seldom found under cobbles less than $15 \mathrm{~cm}$ length. There will also be other considerations in the choice of materials to create refuges; practical, economic and aesthetic. If taken into account at the planning stages of a project, they will not necessarily add to the cost of construction.

Measures implemented for other species can sometimes have benefits for whiteclawed crayfish as well. The Eden Rivers Trust, based in Appleby, Cumbria, is tackling problems such as excessive erosion and siltation due to agriculture throughout the catchment of the River Eden. The River Eden and tributaries is a clean and very varied, northern limestone river, one of the UK SAC rivers for white-clawed crayfish and for several other species. Details of the SAC River Eden are given on the following web site: http:// www.jncc.gov.uk/ProtectedSites/SACselection/sac.asp?EUCode=UK0012643 and about the Eden Rivers Trust on http://www.edenriverstrust.org.uk/. One of the aims of the Trust is to reduce the degree of siltation in the spawning areas used by salmonid fish and hence to improve recruitment. Measures being promoted are fencing both sides of watercourses wherever farmers agree to the work, making alternative provision of water for livestock and restoring actively eroding banks using living willow stakes. This type of river restoration work has a wide range of benefits. Crayfish will benefit from the protection of stream banks from excessive trampling by cattle and sheep. Bank complexity will be retained, or restored over time and reduced siltation will also be beneficial. Baseline surveys of crayfish have been undertaken in some tributaries (PEAY, 2002b), but there is not yet enough survey data before and after fencing to show whether the crayfish population responds significantly to the improvements in the riparian zone.

Given the highly patchy distribution of crayfish, even in streams with abundant populations, it helps in planning a project if there is information about the distribution 


\section{Table II}

\section{Creating refuges for white-clawed crayfish.}

\section{Tableau II}

Créer des refuges pour les écrevisses à pattes blanches.

\begin{tabular}{|c|c|}
\hline Creating refuges & Comments \\
\hline $\begin{array}{l}\text { Stone on the bed } \\
\text { Place large cobbles or boulders ( }>20 \mathrm{~cm} \text { across) on } \\
\text { the bed. Stack to leave gaps for crayfish. }\end{array}$ & $\begin{array}{l}\text { Best in deeper areas not regularly exposed by } \\
\text { changing water level. }\end{array}$ \\
\hline $\begin{array}{l}\text { Stone along banks } \\
\text { Place large cobbles or boulders (>20 cm across) in } \\
\text { the margins. } \\
\text { Can stabilise eroding slope with unmortared stone. } \\
\text { Use unfaced stones or gaps between will not be big } \\
\text { enough. }\end{array}$ & $\begin{array}{l}\text { Not useful if banks are mainly exposed, or shallow } \\
\text { water adjacent. Crayfish like vertical banks with } \\
\text { projecting stones and tree roots below water level. } \\
\text { Gabion baskets filled with stone }<15 \mathrm{~cm} \text {, do not have } \\
\text { gaps big enough for crayfish, except a few juveniles. }\end{array}$ \\
\hline $\begin{array}{l}\text { In highly modified river channel or canal can create } \\
\text { new bank. Drive stakes into bed of channel margin. } \\
\text { Backfill with large stone } \\
(>20 \mathrm{~cm}) . \text { Cover with soil. Can re-seed, turf, plant } \\
\text { trees. }\end{array}$ & $\begin{array}{l}\text { In river, consider effects on flow, including scour } \\
\text { elsewhere. In canal consider navigation. Could make } \\
\text { a good fishing platform in a lake. }\end{array}$ \\
\hline $\begin{array}{l}\text { Wood or vegetation along banks } \\
\text { Plant trees along banks for shade. }\end{array}$ & $\begin{array}{l}\text { Trees on vertical, slightly undercut banks are best, } \\
\text { with large roots and a pool below. If have too many } \\
\text { trees will lose most aquatic vegetation. Tree roots } \\
\text { can cause leakage in clay-lined waterbodies or } \\
\text { dams. }\end{array}$ \\
\hline $\begin{array}{l}\text { If have to stabilise bank can use stakes with } \\
\text { branches interwoven (basket-weave spilling). } \\
\text { Can use faggots for facing bank - small twiggy stems } \\
\text { tied in a bundle, then pegged across exposed bank. }\end{array}$ & $\begin{array}{l}\text { Willow walls need maintenance - coppicing and/or } \\
\text { cut and weave. Faggots need replaced over time. }\end{array}$ \\
\hline $\begin{array}{l}\text { Artificial refuges } \\
\text { Attach short sections of plastic pipe to structures } \\
\text { (bridges, walls etc.), use } 20-50 \mathrm{~mm} \text { diameter. Can } \\
\text { attach plastic mesh or hessian sacking to pipe } \\
\text { area and bed to encourage crayfish to climb up to } \\
\text { refuges. }\end{array}$ & $\begin{array}{l}\text { Can use these in canals or highly modified rivers, } \\
\text { e.g. where essential engineering works cause loss } \\
\text { of bankside habitat. }\end{array}$ \\
\hline $\begin{array}{l}\text { Drill holes c. } 20-50 \mathrm{~mm} \text { into sheet piling near the } \\
\text { channel bed and at various levels above the bed } \\
\text { to allow access to bank. Or, leave gaps, c. } 50 \mathrm{~mm} \\
\text { between sheets, or cut/leave "letter-box" slots, } \\
\text { backfill with coarse fill if necessary. }\end{array}$ & $\begin{array}{l}\text { Crayfish will not swim up to holes so must be able to } \\
\text { climb. Future siltation may cause bed to cover holes } \\
\text { over time, hence need holes at different levels. }\end{array}$ \\
\hline $\begin{array}{l}\text { Face wall or hard bank with layers of brick set on } \\
\text { side, with holes facing outward. } \\
\text { Standard concrete block (breeze-block), place on } \\
\text { side. Pack space with sections of plastic pipe } 20-50 \\
\mathrm{~mm} \text { diameter. Glue in place, or bed into mortar at } \\
\text { the back. Set at right angles to flow. }\end{array}$ & $\begin{array}{l}\text { Can use this under bridges and in large culverts. In } \\
\text { culverts can use the brick or blocks with cavities to } \\
\text { support a dry ledge that can be used by otters or } \\
\text { other mammals. }\end{array}$ \\
\hline $\begin{array}{l}\text { Take either coarse hessian sacking or plastic netting } \\
\text { (e.g. strawberry net). Fill loosely with straw in a } \\
\text { 'pillow' or 'sausage'. Peg bag to bed in submerged } \\
\text { margins. }\end{array}$ & $\begin{array}{l}\text { Good for juveniles. Can use in a lake or gravel pit. } \\
\text { Using nets with barley straw close to water inlets } \\
\text { helps reduce growth of algae. Replenish straw every } \\
\text { year or two. Can make juveniles easier to detect in } \\
\text { surveys, if sample the bags. }\end{array}$ \\
\hline
\end{tabular}

Table reproduced from Peay, 2003b. 
of crayfish and relative abundance in the area that will be affected by works. Semiquantitative surveys are recommended. Where crayfish have to be removed from an area of works there is value in obtaining as much detailed information as is practicable about the population. De-watering is a damaging operation. Where it cannot be avoided and is localised, it can provide a method of estimating population density that is not generally available. In the muddy conditions of a construction site, there will always be an underestimate of the juvenile population, even with plenty of well-briefed helpers to retrieve the animals. Nonetheless, comparisons between prior surveys and "total" removal are of value in assessing the relative efficiencies.

If crayfish are removed from an area affected by works, they can be relocated within the same watercourse in favourable habitat, supplemented by additional refuges if necessary. If the works are extensive, capture or recapture from the unaffected areas and re-introduction to the affected area could be considered. White-clawed crayfish can be kept in captivity, but this involves space, equipment and time, which add to the cost of the project. In most cases it is preferable to keep populations in the wild and close to the site of works.

Construction work is not always damaging in the long term. De-silting of a river, lake or canal will undoubtedly have impacts at the time of works, but may expose or allow the provision of new refuges for crayfish. If banks and margins are retained undisturbed, crayfish may be able to recolonise readily. Some types of bank reinforcement, as shown in Table 2, can provide complexity of structure and hence offer refuges that would be absent in highly modified waterbodies with uniform sloping banks.

The impact of construction on particular populations of crayfish depends on the population and habitat that will be affected and on the specific detail of works. Mitigation measures need to be carefully tailored to the individual sites and works to be successful. Considering what constitutes favourable habitat for individual crayfish will help in the design of measures that work at a site scale.

\section{CONCLUSIONS}

The biggest threats to white-clawed crayfish in England are the risk of invasion of non-indigenous crayfish, crayfish plague and the water quality and landuse in the catchment. The first two factors are also by far the most difficult to control. Despite the increasing impact of non-indigenous crayfish, white-clawed crayfish still survive in a wide range of habitats in England; from upland, limestone streams, to lowland rivers, canals, ponds and quarries. Despite this, populations may be lost, or at least partially isolated, by areas of unfavourable habitat, either from past modification of rivers, or new works.

Construction work can cause temporary or permanent loss of both habitat and populations. The impacts occur from direct loss of refuges in banks and channel. They may also occur from de-watering operations or pollution incidents. Whilst pollution risk can be minimised by good construction practice, specific mitigation measures are needed to minimise impacts on white-clawed crayfish. This may involve removal of crayfish from the working area and re-instatement of habitat afterwards, if possible.

Mitigation measures are not always applied and even where they are, they may have only partial effectiveness. Individual projects may be localised or extensive. Recovery of white-clawed crayfish populations may take several years, even if good habitat is still available after works. Post-project monitoring is rarely carried out. This means problems may not be identified and may be repeated in schemes in future.

Although a project may involve advance surveys and planned mitigation measures, the success of these depends on the detail of how they are implemented during 
construction. Good site supervision is essential. Construction work involving watercourses is still subject to all the usual vagaries of breakdowns, problems with staffing, poor weather conditions and other unplanned events. Even with a good environmental site manager and one or more ecologists with specialist knowledge of crayfish on hand, measures will not always work as planned. Good construction management will include an environmental risk register and contingency plans for the problems that are most likely to occur. Once the work on site is finished, unless an outcome is explicitly detailed as a planning condition, it is difficult to ensure any remedial work or improvement is undertaken retrospectively.

To be as effective as possible, mitigation measures for works affecting white-clawed crayfish need the following:

- advance surveys;

- measures to minimise losses of crayfish during works;

- measures to reinstate or compensate for loss of habitat;

- mitigation measures incorporated into the design and the detailed method of work and adequately allowed for in the budget;

- good control of works on site and in the detail of reinstatement, including good staff briefing and supervision;

- contingency plans to cope with weather, breakdowns, spillages and other events;

- good data collection and full reporting, including acknowledgement of problems or deficiencies, to enable better planning of future projects, and

- subsequent monitoring, preferably budgeted into the project at the start.

There is still scope for improvement in measures to minimise the impacts of construction on white-clawed crayfish and to provide the best habitat restoration or improvement. Nonetheless, there is a growing awareness among the regulators, environmental consultants, project engineers and contractors that white-clawed crayfish should be taken into account in projects. The more that best practice guidance is made available and is implemented, the better the projects will be in future.

\section{REFERENCES}

ARMITAGE V., 2000. Observations of radio-tracked crayfish (Austropotamobius pallipes) in a northern British river. In: Crayfish Conference Leeds, (eds D. ROGERS and J. BRICKLAND), pp. 63-69. Environment Agency, Leeds.

BRICKLAND J., 1996. A survey investigation of habitat types in relation to the occurrence of the British white-clawed crayfish Austropotamobius pallipes, in Meanwood Beck and Wyke Beck Leeds. Internal report, Environment Agency, North East Region, Ridings Area, Leeds. 9 p.

BROWN K. 1996. A population study of white-clawed crayfish Austropotamobius pallipes in the Meanwood Beck catchment, Leeds. MRes Ecology and Environmental Management University of Leeds, $27 \mathrm{p}$.

FOSTER J. 1993. The relationship between refuge size and body size in the crayfish Austropotamobius pallipes (Lereboullet). Freshwater Crayfish, 9, 345-349.

HOLDICH D.M., ROGERS W.D. and READER J.P., 1995. Crayfish Conservation. Final project report record to National Rivers Authority 1995. NRA R\&D 378/10/N National Rivers Authority, Bristol, 278 p.

PEAY S., 1997. Night survey for crayfish in the River Wharfe, Yorkshire. MSc dissertation, University of Hull, $126 \mathrm{p}$. 
PEAY S. and ROGERS W.D., 1999. The peristaltic spread of signal crayfish (Pacifastacus leniusculus) in the River Wharfe, Yorkshire, England. Freshwater Crayfish, 12, 665676.

PEAY S., 2000. Guidance on Works Affecting White-clawed Crayfish. English Nature, Peterborough, $27 \mathrm{p}$.

PEAY S., 2002a. Long Preston Beck Bank Reinforcement - Mitigation For White-Clawed Crayfish Railtrack Pd North West SKWI Bridge No. 39 Long Preston, 2002-2003 Remit. Unpublished report to Edmund Nuttall Ltd, $11 \mathrm{p}$.

PEAY S., 2002b. Monitoring Protocol for White-clawed Crayfish, Field-testing in River Eden Tributaries, Summer 2002. Life in UK Rivers Project. Contract LIF 02-11-37. English Nature, Peterborough, $57 \mathrm{p}$.

PEAY S., 2003a. Monitoring the White-clawed Crayfish Austropotamobius pallipes Conserving Nature 2000 Rivers Monitoring Series No. 1. English Nature, Peterborough, $58 \mathrm{p}$.

PEAY S., 2003b. Guidance on habitat for white-clawed crayfish and how to restore it. R\&D Technical Report W1-067/TR. Environment Agency, Bristol, 66 p.

ROBINSON C.A., THOM T.J. and LUCAS M., 2000. Ranging behaviour of a large freshwater invertebrate, the white-clawed crayfish Austropotamobius pallipes. Freshwater Biology, 44, 509-521.

SCOTT WILSON, 1998a. Crayfish translocation in Meanwood Valley. Unpublished report to Johnston Construction Ltd, $10 \mathrm{p}$.

SCOTT WILSON, 1998b. Crayfish Report Settle-Ingleton Improved Water Supply. Unpublished report to Birse Construction Ltd, 23 p.

SIBLEY P.J., BRICKLAND J.H. and BYWATER J.A., 2002. Monitoring the distribution of crayfish in England and Wales. In Knowledge-based mangement of European native crayfish. Crayfish special Vol. 4 (eds C. SOUTY-GROSSET \& F. GRANDJEAN). Bull. Fr. Pêche Piscic. 367(4), 833-844.

SIBLEY P.J., 2003. The distribution of crayfish in Britain. In (eds D.M. HOLDICH and P.J. SIBLEY). Management and Conservation of Crayfish. Proceedings of a conference held on 7th November, 2002. Environment Agency, Bristol, 217 p.

SMITH G.R.T.; LEARNER, M.A., SLATER F.M. and FOSTER J., 1996. Habitat features important for the conservation of the native crayfish Austropotamobius pallipes in Britain. Biological Conservation, 75, 239-246.

SPINK J. and FRAYLING M., 2002. An assessment of post-plague reintroduction of native white-clawed crayfish Austropotamobius pallipes in the Sherston Avon, Wiltshire. Freshwater Forum, 14, 59-69.

TAYLOR E.W. and WHEATLY M.G., 1981. The effect of long-term aerial exposure on heart rate, ventilation, respiratory gas exchange and acid-base status in the crayfish Austropotamobius pallipes. Journal of Experimental Biology, 92, 109-124. 